\title{
Telecommuting: A Panacea to COVID-19 Spread in Nigerian Universities
}

\author{
${ }^{1}$ Pauline E.Onyeukwu, ${ }^{2}$ Abiodun Adeniyi, ${ }^{3}$ Hindu J.Amin \\ 1,2,3 Faculty of Management and Social Sciences, Baze University, Abuja, Nigeria
}

\begin{abstract}
The paper examines how telecommuting could serve as a panacea to the spread of COVID-19 in Nigerian Universities. The research sample consists of 119 respondents, of which 36 are lecturers and 83 are students. The primary source was used in data collection with a structured questionnaire which employed five-point Likert - scale. The questionnaire was administered to respondents online via Google forms (https://bit.ly/3cdbkSZ). The study adopted the qualitative and quantitative data analysis method. ANOVA, Correlation and Regression analyses were used to test the Hypotheses with the Statistical Package for Social Sciences (SPSS) version 25. The Cronbach Alpha test was adopted for the establishment of reliability Coefficient. The findings revealed that Telecommuting strongly affects the spread of COVID-19. Furthermore, we found that online teaching could help with social distancing. Social media has a negative correlation with community spread of COVID-19, while video conferencing has a positive impact on the importation of COVID-19 and that Internet usage could curb the spread of coronavirus in Nigerian University. The study concludes that telecommuting is an effective strategy the Nigerian Government should adopt in the educational sector to avoid any future disease spread that would disrupt the academic activities. The paper recommends that the ministry of health should enforce all the Institutions of learning in Nigeria from primary to Tertiary to be Information Communication Technology, (ICT) compliance to enable telecommuting to be active and efficient.
\end{abstract}

Keywords: Panacea, Pandemic, Telecommuting and University

\section{Introduction}

Telecommuting is the process of working from home with the use of internet, Email and Telephone. Telecommuting could also be called telework or teleworking, and this concept of remote working is spreading worldwide. Many organizations are adopting it to avoid office congestion and make use of their flex-time to be productive. The word telecommute means to work from home, communicating with your office, customers and others by telephone, emails and online (Hornby et al., 2010). A teleworker could use teleconferencing to hold meetings, i.e., a conference or discussion is held where members from different locations are able to interact using on-line tools like Zoom, Goole Meet, WhatsApp and other communication means, such as video and telephone. Telecommuting thus involves performing work from home or another remote location with the use of computers and telecommunicating equipment (Daft, 2010).

The presence of the Third-wave has taken the front stage globally, the western world and global south alike. Electronic learning has surpassed the traditional form of learning adopted the educational sector before the crisis. In the 1990s, organizations usually utilized a particular room for holding videoconferences, equipped with television cameras, but today, one can participate in videoconference without leaving office, due to the modern computers and telephones with integrated camera and microphones (Robbins, Timothy and Seema, 2008). 
Working from home with a terminal which linked to the central organization or networked with other workers is teleworking (Armstrong, 2006).

Telecommuting is the concept of working from home by using a computer, telephone, email and internet. Globalization made the process of working from any location reasonably easy because the world is like a village. Unlike today, most of the computers and phones in the 1980s and 90 s did not have inbuilt cameras and microphone. As a result of the upgrade, telephones and computers with in-built cameras and microphones facilitated the workflow, so business can now be carried out from home as it would be in an office setting, but with less stress. Nigeria has 92.3 million internet users, and the number is expected to increase to 187.8 million in 2023. This shows that internet penetration in the Nigerian population was 47.1 per cent in 2018 and is expected to grow to 84.5 per cent in 2023 (Clement, 2019). Nigeria was ranked as the $47^{\text {th }}$ in Saharan Africa and the $21^{\text {st }}$ out of $65 \mathrm{global}$ in terms of internet freedom (Freedom House Index, 2019). Internet usage in Nigeria is of great advantage to telecommuting in learning and teaching. The mobile phone internet is common among Nigerians, with almost 50 million people accessing mobile internet with smartphones (clement, 2019). The use of internet, telephones and other social media, like zoom, Google class and meet, WhatsApp etc. make remote activities effortless and less stressful. Remote access allows the use of a computer system, telephone, email, etc., from another location by connecting with the electronic link, (The Webster's Comprehensive Dictionary, 2003). Remote access makes lecturing from home effortless and enjoyable and enables the lecturer and students to interact as if they were in a regular classroom via Videoconferencing, Skype, Google Meet, WhatsApp video, Zoom app, etc.

Many researchers have studied the impact of online studies in Nigerian educational sector, Onyeukwu, Akanegbu, and Igbokwe, 2017). The introduction of telecommuting in Nigerian learning institutions has a lot of benefits for both students and lecturers. In a situation where telecommuting is applicable in any learning institution; the classes are not usually interrupted.

Coronavirus, which was nicknamed COVID-19 started in Wuhan in China in late 2019 and the virus has been causing havoc around the world ever since. An Italian has brought the virus to Nigeria. The economic, social and educational progress of many countries has been disrupted. The ugly pandemic of COVID-19 caused many lockdowns and disruption in the activities of many sectors, and schools were shut down. It became urgent to apply telecommuting practice in teaching from home to students all over the country. Telecommuting remains the only tool that could be used to overcome the COVID-19 pandemic in Nigerian educational sector. However, the concept is having some challenges, such as; inadequate electric power supply, high cost of airtime, poor network service from network providers. These problems have been hampering the efficiency and effective use of remote work activities, social distancing and online teaching in Nigerian Universities. These challenges led to finding a proper solution.

The questions raised in the study are, the main problem is, to what extent telecommuting affects COVID-19 spread in Nigerian Universities? How has online teaching affected social distancing in Nigerian Universities? What is the effect of social media on COVID-19 importation in Nigeria? To what extent has Video conferencing impacted physical contact spread of COVID-19 in Nigerian Universities? To what extend has internet usage affected the community spread of COVID-19 in Nigerian Universities? The main aim of the study is to examine the effect of Telecommuting on the COVID-19 pandemic in Nigerian Universities, other objectives that were raised in line with research questions are as follows: to determine how online teaching affects social distancing in Nigerian Universities; to highlight the effect of social media on the importation of COVID-19 in Nigerian Universities, to examine the impact of video conferencing on the physical contact spread of COVID-19 in Nigerian Universities and test the effect of internet usage on community spread of COVID-19 in Nigerian Universities.

Null Hypotheses were formulated to guide the study in line with research questions and objectives: Ho1: Online teaching has no significant relationship with Social distance in Nigerian 
Universities. Ho2: Social Media has no significant relationship with the COVID-19 importation in Nigerian Universities. Ho3: There is no correlation between Video conference and physical contact spread of COVID-19 in Nigerian Universities.Ho4: Internet usage does not affect the community spread of COVID-19 in Nigerian Universities. Ho5: There is no significant relationship between Telecommuting and COVID-19 pandemic in Nigerian Universities.

The study develops recommendations for the Nigerian Government in policy formulation concerning the Nigerian educational sector. This will provide University management in Nigeria with an alternative for mitigating the harmful effects of any future disease outbreak with the ability to disrupt educational and school activities. The study contributes to the body of knowledge and can serve as reference material for other researchers.

The study was carried out on a sample of 119 respondents, consisting of lecturers and students in Abuja Nigerian Universities.

\section{Literature Review}

\subsection{Conceptual Framework}

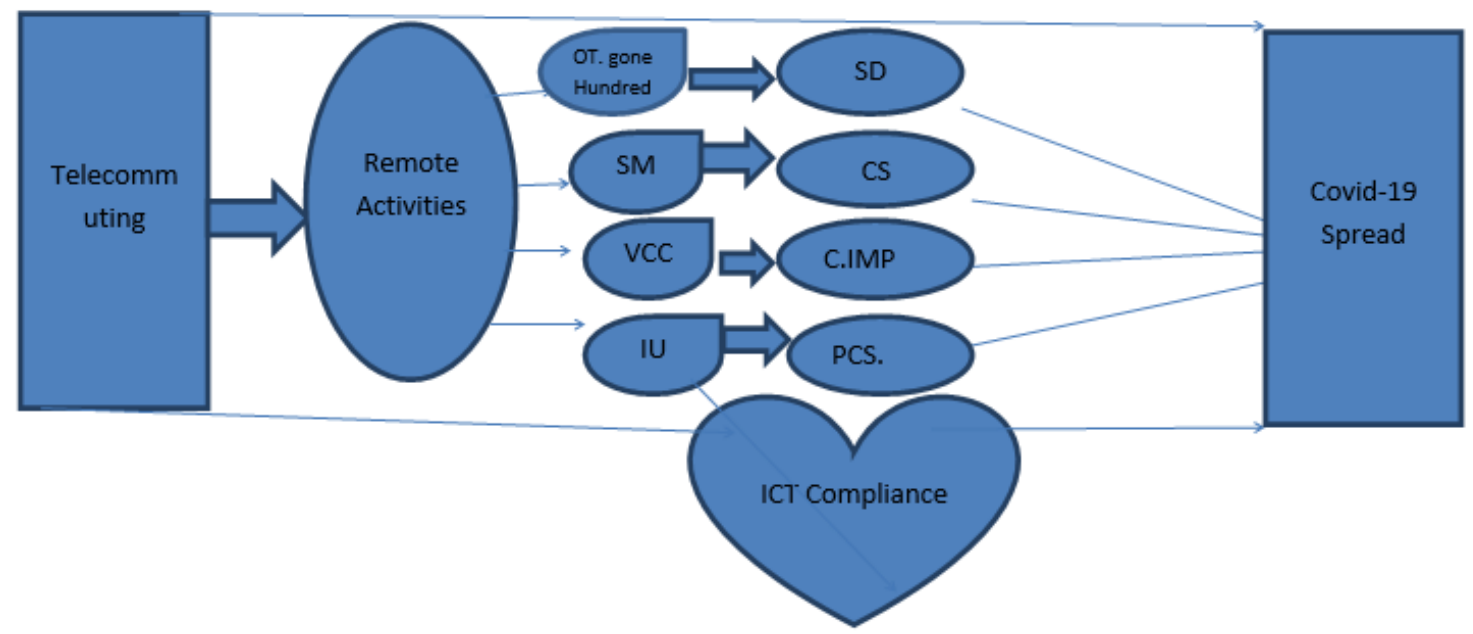

Figure 1: The Conceptual Framework of Telecommuting and Covid-19 Spread.

Source: Authors Design; 2020: The relationship between the Independent and Dependent Variables with their proxies.

\subsection{Theoretical Review}

Every organization aims to achieve its objectives through human resources aligning with organizational objectives. There should be an underlying conceptual framework guiding corporate strategy, and it is of utmost importance that each practice relies on the existing theory, to measure its performance.

To design our study, we draw from the theoretical framework of Michigan Theory, also known as a Matching model applicable in telecommuting. Fombrum, Tichy and Devana (1984), believe that organizational structure and employees should be managed in such a way that is consistent with long term corporate objectives. Some Nigerian Universities are world-renowned for their ICT compliant standards which allow them to stay competitive in a global environment. Many private schools in Nigeria have robust Information Communication Technology (ICT). They have world-class lectures and ICT Engineers. The Michigan theory, even though it is hardly model, provides essential support to the study. 


\section{Pauline E.Onyeukwu, Abiodun Adeniyi, Hindu J.Amin \\ Telecommuting: A Panacea to COVID-19 Spread in Nigerian Universities}

Even when working from home, telecommuters are required to meet the University's standards. The theory takes cognizance of a tight-fit match, such as selection, performance, appraisal, reward and development. That is to say, all University's procedures and policies apply the same regardless of the lecturer's location; therefore, telecommuting must strictly adhere to the process.

Harvard Theory (Beer et al., 1984) focuses on working systems, stressing people should be aligned with work design. Employees are the most valuable organizational asset; therefore, they should be treated with respect. In telecommuting, every lecturer would depend solely on her/his modules and should be given full privacy while designing courses without unnecessary monitoring. When a lecturer is treated with respect, she/he will show commitment, congruence, competence and cost-effectiveness. This study supports the Harvard model, stressing that if lecturers are well-motivated, the work they conduct from home does not differ in quality from the lectures carried out in physical classrooms.

Resource Base Theory posits that resources are scarce, and if employees are properly managed, they will bring long term advantage to the firm. In a situation where coronavirus is causing havoc worldwide, this theory holds even more, since working from home will protect both the students and the lectures from the infectious virus. Life cannot be duplicated, as such, students and lecturers should be maximally protected at all cost. The only way to achieve this during a pandemic is through telecommuting. Therefore, our study supports the theory.

Other theories that are applicable to telecommuting are Agency Theory, Institutional Theory and Exchange theory. Agency theory stresses that the University Management should consider monitoring and controlling employees' activities. Using remote access to work from home requires some level of surveillance by the University to ensure compliance. The ICT department could monitor lecturers and student portals to see to what extent they are participating in the class activities. All first-class private Universities in the country draw from this theory. Therefore, remote working is paramount to curb the pandemic of COVID-19 in Nigerian Universities.

Exchange Theory is critical in telecommuting, addressing the way organizational management rewards the employees for the costs incurred during the interaction. University Management should try to reward employees' performance equally (Onyeukwu and Mehmet, 2012). While telecommuting from home, specific packages should be given to those lecturers, like e-top up, a stipend to purchase fuel because electricity power failure is usually high in Nigeria, and to make sure their salaries are paid in time. This will motivate lecturers to put in their best, which will, in turn, increase organizational productivity.

Institutional Theory is concerned with organizational ethics. Every University has its guidelines, norms, procedures and culture, and the same organizational cultures and climate are to be maintained while telecommuting. Lecturer and students should still maintain the expected relationship in line with the University's guidelines.

The Institutional Theory is the theoretical basis for this study. According to Powell and Di Maggio (1991), an organization's practice and standard should in the interest of the organization, and should also be legitimate and accepted by the key stakeholders. Nigerian Universities must follow the National University Commission, (NUC) while using remote access in teaching and learning. The agency and institutional theories support the study of (Westfall 2007), titled, The Telecommuting Paradox. The study helps to promote telecommuting's institutional right and is hugely beneficial to the employees and the organization.

\subsection{Empirical Review}


Some researchers have studies telecommuting in the workplace. For instance, Pauline, Benedict, and Anthony (2016) conducted the study in Abuja, Nigeria on a sample of twenty public and private Universities. The study explored how the Third wave could be used to enhance lecturing. Findings show that the use of e-learning through online teaching has improved literacy in Nigeria. It also revealed that private Universities are using third wave technologies maximally in their academic activities among their lecturers and students. Our research is in line with their results since telecommuting requires remote access in its operations. The social distancing can help to curb COVID-19 pandemic, and in academia, this is accomplished through teaching and learning from home.

The study of Spillman and Markham (2016) examined experts on the merits and the shortcomings of telecommuting for employees and the organization. They stress telecommuting as an alternative work arrangement, and we support their conclusions considering there is no best way of doing things. Nigerian University should use Telecommuting as an alternative in their Institution, as it will allow them to overcome any unforeseen circumstances that could interrupt their academic calendar.

Ellis and Webster (2016) used the structural equation model in their study to investigate the factors affecting telecommuting on a sample of Information systems managers. Their study revealed that organizational and personal innovative factors were significant in their model. Our research conforms with their results since telecommuting encompasses working from a remote location with the aid of telecommuting equipment, such as a personal computer or cell phone. That is to say that, a University must be ICT compliant; with digitally literate students and lecturers before telecommuting may be possible. Many Universities in Nigeria, especially Private Universities, like Baze University, are 100 per cent ICT compliant.

Guthrie (2007) studied the ethics of telework by surveying 18 ethical scenarios involving teleworkers, their managers and their organizations. He tackled an issue of trust, time versus quality and job description. The study concludes that corporate policies adhering to the interest of all stakeholders could solve those problems. We conform to this view. In a situation where lectures are motivated, they will put in their best in teaching students; and this would enhance the University productivity.

Stephens and Szajna (2015) used the interview method with 26 employees' who are telecommuters in their organizations to understand the merits and challenges of telecommuting. The study shows that telecommuting is both instrumental and emotional. More precisely, it provides a relaxed atmosphere in the home setting while working. It is also cost-effective due to the lack of office politics and time management. On the other hand, working from office could enhance social interaction, direct supervision and improve differentiation between home and work life. Our study is in line with their assertions; however, our research refutes their conclusions regarding social interaction, direct supervision and separation between home and work life. We assume this can be achieved through social media. Lectures are more concentrated while working from home because there would be no distraction from students and colleagues.

Charalampous, Grant, Tramontano and Michallidis' study (2018) points to the association between remote e-working among teleworkers and the five dimensions of well-being; namely, affective, cognitive, social, professional and psychosomatic. The study suggests that the affective, social and professional states of remote e-workers are more accessible than their cognitive and psychosomatic conditions. This study agrees with their findings because the cognitive and psychosomatic state of a lecturer and students might not be evident through remote activities. However, the research focuses only on the learning that could be uninterrupted amid pandemic like COVID-19. 
In the work of Duxbury, Higgins and Irving (2016), attitudes of 78 managers and 63 digitally literate employees are compared. Findings show that both groups did not find the concept interesting; their organizations were not in full support of telecommuting. This is because they are concerned with social interaction, professional development and promotion. Their study is done under normal conditions in a stable period; in the year 2016, there was no COVID-19 pandemic ravaging the world.

At this time, we are discussing Physical Distancing and not social Distancing (Ihekweazu, 2020). Their arguments were unacceptable as far as this study is concerned, this is because telecommuting has to do with the social network that enhances social interactions. Videoconferencing, WhatsApp, Google meet, etc. are all means promoting social interaction without necessarily involving physical contact. The adage that says, that practice makes perfect disallows their view on professional development. This is because; tools like YouTube may be utilized to learn and acquire new professional skills. Regarding the promotion, every University has its guidelines, and regardless of where the faculty is working from, once the requirement is met, the lecturer would be promoted. The use of the internet and social networks would allow the lectures to publish papers faster.

Fay and Kline (2011) applied the structuralist and constructivist theories to examine the coworker relation in a high-intensity telework organization. They found co-worker relations are satisfactory, and so is their informal communication. This is contrary to the schools of thought that suggest that telecommuting hinders social interaction. Their study is in line with other researches (Fonner \& Roloff 2010; Anderson, Kaplan\& Vega, 2015)

Khalifa and Etezadi (2016) examined the beliefs of managers and non-managers using exploratory factor analysis to determine the anticipated effects of employees' belief toward telecommuting. Their findings show five positive and two negative beliefs. The positive aspect is that telecommuting would better the life of telecommuters, enhance productivity, improve company's appeal to employees and also affect the environment and society positively. On the other hand, they were of the view that the concept would hamper users' career development and hinder management from controlling their staff.

This study supports their results because telecommuting would help lecturers and students to stay healthy. Coronavirus is a nasty pandemonium virus that is ravaging the whole world, and the adoption of telecommuting will help to continue with academic efforts while staying safe. The Universities will have higher productivity, cut expenses on office paper-work and achieve cost-effectiveness. This is because all the learning, training and communication are done through the internet, intranet, emails and other social networks. We refute their negative beliefs because in every University lecturers and students have their timetable which the school management is aware of. Therefore, the fear of losing control is not plausible in ICT compliance Universities. Career development is better while telecommuting because the commuter is working without stress.

The paper by Handy and Mokhtarian (2007), carried in California explained the hiccups in interpreting and reconciling the available data of telecommuters. They stressed that the percentage of telecommuters differs through commuting occasions. They also explain the roles the planners have played in encouraging and discouraging telecommuting. Authors are critical of adopting Telecommuting in Nigerian Universities. Some challenges like poor electricity power distribution, poor network service, cyber-hackers should be considered while initiating telecommuting in Nigerian Universities.

Another interesting work of Guimaraes and Dallow (2017), provides empirical evidence of the positive, negative and success factors for telecommuting programmes. Their results are in line with Tustin' (2014), whose study is titled telecommuting academics within an open distance 


\author{
Pauline E.Onyeukwu, Abiodun Adeniyi, Hindu J.Amin \\ Telecommuting: A Panacea to COVID-19 Spread in Nigerian Universities
}

education environment of South Africa: more content, productive and healthy? The researcher did a comparative study between telecommuting and non-telecommuting academics. The research shows high level work productivity and satisfaction among lecturers and students. We agree with his conclusions, positing that telecommuting will not only satisfy the lecturers and students in Nigerian Universities, but it would also keep them alive amid COVID-19 pandemic.

The Virus is pandemonium, and Nigerian Universities could only avoid its spread with the telecommuting strategy. This is in line with Baba-Ahmed's (2020) article titled: A second Approach to COVID-19. He says, the only difference between a dangerous virus and a nuclear weapon is perhaps the mushroom cloud; 'they explode, destroy and change the course of human history'. He recommends that an alternative course of action should be taken now. We support his view considering presently, students of all Nigerian academic circles, including primary, secondary and Tertiary education are out of school. Therefore, it is imperative that telecommuting should be put in place immediately to salvage the damage the pandemic coronavirus has caused in the education sector in Nigeria. Telecommuting should be used during and post COVID-19; this will enable the Nigerian Universities to be proactive, not reactive.

\title{
3. Methodology
}

This paper made use of cross Sectional Survey research design. The research sample consisted of 119 lecturers and students of Universities in Abuja. The probability sampling strategy was adopted in this paper because of its importance in quantitative approach. The primary source was used in data collection with a structured questionnaire which employed five-point Likert scale. The questionnaire was administered online to respondents via Google forms (https://bit.ly/3cdbkSz).

The study made use of descriptive and inferential methods in data analysis. The descriptive statistics were used for the understanding of the data while the inferential method was used to test the Hypotheses. Correlation, Analysis of Variance (ANOVA) and Regression analyses with the use of Statistical Package for Social Sciences (SPSS) version 25 was used in testing the Hypotheses. The Cronbach Alpha test was adopted for the establishment of reliability Coefficient. A reliability coefficient of 0.7 and above, are high and acceptable, while a reliability coefficient of 0.6 and below shows poor reliability. Thus, the reliability coefficient for this study settled at 0.7 and above.

\subsection{Model Specification}

Model specification of the relationship between Telecommuting ( $T$ ), Online Teaching (OT), Social Media (SM) Video conferencing (VC) Internet Usage (IU) and COVID-19 spread is supported by existing theoretical frameworks and empirical evidence from previous studies. Researchers have decided to specify the relationship between the independent and dependent variables with their proxies as follows:

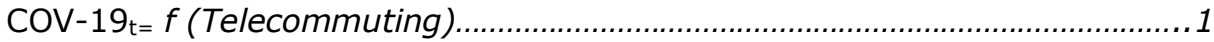

Telecommuting $=f(O T, S M, V C, I U)$......................................................

Substitute equation two in one; therefore, we have equation three.

$\mathrm{COV}-19_{\mathrm{t}}=\beta_{0}+\beta_{1} O T_{t}+\beta_{2} S M_{t}+\beta_{3} V C_{t}+\beta_{4} I U_{t}$

But the equation above is exact or deterministic. To allow for the inexact relationship among the variables as in the case of most economic variables, stochastic error term " $\mu_{\mathrm{t}}$ " is added to the equation. Thus, we can express the econometric form of the model as:

COV $-19_{t}=\beta_{0}+\beta_{1} O T_{t}+\beta_{2} S M_{t}+\beta_{3} V C_{t}+\beta_{4} I U_{t}+U_{t}$

Where:

COV-19 spread $=$ COVID-19 spread is the dependent variable. 
Pauline E.Onyeukwu, Abiodun Adeniyi, Hindu J.Amin

Telecommuting: A Panacea to COVID-19 Spread in Nigerian Universities

OT =Online Teaching an independent variable which represents one of the proxies for Telecommuting.

SM = Social Media is an independent variable which represents one of the proxies of Telecommuting.

VC $=$ Video conference is an independent variable which represents one of the proxies for telecommuting.

IU = Internet usage is an independent variable which represents one of the proxies for Telecommuting.

$\beta_{0}=$ Stands for intercept

$\beta_{1}, \beta_{2}, \beta_{3}$, and $\beta_{4}$ stand for the coefficient of $\mathrm{OT}_{t}, \mathrm{SM}_{t}, \mathrm{~V} \mathrm{C}_{\mathrm{t}}$ and $\mathrm{IU}_{\mathrm{t}}$

$\mu$ : the stochastic error term. This is introduced into the model to capture all

\section{Data Analysis and Interpretation}

This section deals with the validation of the formulated hypotheses using inferential analyses as well as some relevant data collected for the study. The inferential statistics used are simple regression, ANOVA and correlation techniques. They are tested as follows:

Table-1: Respondents demographics

\begin{tabular}{|c|c|c|c|}
\hline \multicolumn{4}{|c|}{ Respondents demographics } \\
\hline Items & Options & $\begin{array}{c}\text { Frequency } \\
\text { (116) }\end{array}$ & Per cent \\
\hline \multirow{5}{*}{ Age } & $18-24$ years & 40 & 34.5 \\
\hline & $25-34$ years & 28 & 24.1 \\
\hline & $35-44$ years & 12 & 10.3 \\
\hline & $45-54$ years & 22 & 19.0 \\
\hline & 55 years and above & 14 & 12.1 \\
\hline \multirow{2}{*}{ Category } & Lecturer & 33 & 28.4 \\
\hline & Student & 83 & 71.6 \\
\hline \multirow{4}{*}{ Educational attainment } & College & 2 & 1.7 \\
\hline & Postgraduate & 77 & 66.4 \\
\hline & Secondary Sch & 1 & 0.9 \\
\hline & Undergraduate & 36 & 31.0 \\
\hline \multirow{2}{*}{ How often do you use internet services? } & Once/week & 2 & 1.7 \\
\hline & Regularly & 114 & 98.3 \\
\hline \multirow{2}{*}{$\begin{array}{l}\text { Physical infrastructure for using } \\
\text { telecommuting [I have a computer, tablet } \\
\text { or smartphone] }\end{array}$} & No & 1 & 0.9 \\
\hline & Yes & 115 & 99.1 \\
\hline \multirow{3}{*}{$\begin{array}{l}\text { Physical infrastructure for using } \\
\text { telecommuting [I have access to the } \\
\text { Internet/data] }\end{array}$} & No response & 5 & 4.3 \\
\hline & No & 2 & 1.7 \\
\hline & Yes & 109 & 94.0 \\
\hline \multirow{3}{*}{$\begin{array}{l}\text { Physical infrastructure for using } \\
\text { telecommuting } \quad \text { I constantly use the email } \\
\text { address }]\end{array}$} & No response & 5 & 4.3 \\
\hline & No & 22 & 19.0 \\
\hline & Yes & 89 & 76.7 \\
\hline
\end{tabular}

Source: Respondents Demographics, 2020

\section{Regression Analysis}

$\mathrm{H}_{01}$ : Online teaching has no significant effect on Social distancing in Nigerian Universities. 


\section{Model Summary}

Table- 2

\begin{tabular}{|c|c|c|c|c|c|c|c|c|c|}
\hline \multirow{2}{*}{$\begin{array}{l}\text { Mod } \\
\text { el }\end{array}$} & \multirow[t]{2}{*}{$\mathrm{R}$} & \multirow[t]{2}{*}{$\begin{array}{c}\text { R } \\
\text { Square }\end{array}$} & \multirow{2}{*}{$\begin{array}{l}\text { Adjuste } \\
\text { d R } \\
\text { Square }\end{array}$} & \multirow{2}{*}{$\begin{array}{c}\text { Std. The } \\
\text { error of the } \\
\text { Estimate }\end{array}$} & \multicolumn{5}{|c|}{ Change Statistics } \\
\hline & & & & & $\begin{array}{l}\text { R Square } \\
\text { Change }\end{array}$ & F Change & $\begin{array}{c}d f \\
1\end{array}$ & $\mathrm{df2}$ & $\begin{array}{c}\text { Sig. F } \\
\text { Change }\end{array}$ \\
\hline 1 & $.732^{a}$ & .600 & .396 & 2.71025 & .600 & 109.210 & 1 & 164 & .000 \\
\hline
\end{tabular}

a. Predictors: (Constant), Online Teaching

Source: Author's Computation using SPSS V. 25.0

The model summary results above show the relationship between online Teaching and social distancing, depicted by the regression coefficient ( $R$ ) Value is .732 (73.2\%). This means that there is a strong relationship between the two variables. Also, as indicated by the table, the variations in social distancing as a result of online teaching are indicated by R-Square value of $.600(60.0 \%)$. This implies that about $60 \%$ variation in social distancing is explained by online education. The remaining $40 \%$ is accounted for by other factors not captured by this study.

Table-3

\section{Coefficients}

\begin{tabular}{|c|c|c|c|c|c|}
\hline \multirow[t]{2}{*}{ Model } & \multicolumn{2}{|c|}{$\begin{array}{l}\text { Unstandardized } \\
\text { Coefficients }\end{array}$} & $\begin{array}{l}\text { Standardized } \\
\text { Coefficients }\end{array}$ & \multirow[t]{2}{*}{$\mathrm{t}$} & \multirow[t]{2}{*}{ Sig. } \\
\hline & $B$ & Std. Error & Beta & & \\
\hline $\begin{array}{ll} & \text { (Consta } \\
1 & \mathrm{nt})\end{array}$ & 20.764 & .819 & & 25.367 & .000 \\
\hline & 2.403 & .230 & .632 & 10.450 & .000 \\
\hline
\end{tabular}

a. Dependent Variable: Social Distancing

Source: Author's Computation using SPSS V. 25.0

The coefficients regression table above shows that Online Teaching has a .632 coefficient Value with the t-statistics value of 10.450 and sig. Value of .000 . The implication of this is that increase in Online Teaching by one per cent, holding other variables constant, will lead to rising in Social Distancing by $63.2 \%$. This result is significant given the Sig. Value (of .000) which is far less than $5 \%$. From the regression result tabulated above, it is apparent that Online Teaching has a coefficient value of .632 with the at-Statistics Value of 10.450 and Sig. Value of .000 . This implies that an increase in Online Teaching by $1 \%$ will lead to $6.32 \%$ increase in Social Distancing, all things being equal. Consequent upon this result, the null hypothesis that says Online Teaching has no significant effect on social distancing is rejected.

\section{Analysis of Variance (ANOVA)}

$\mathrm{H}_{02}$ : There is no significant benefit of using Social Media to curb the COVID-19 importation in Nigerian Universities. 
Table-4

ANOVA

\begin{tabular}{|l|r|r|r|r|r|}
\hline & Sum of Squares & Df & Mean Square & \multicolumn{1}{|c|}{ F } & Sig. \\
\hline Between Groups & 101.555 & 4 & 25.389 & 57.670 & .000 \\
Within Groups & 70.879 & 115 & .440 & & \\
Total & 172.434 & 119 & & & \\
\hline
\end{tabular}

Source: Author's Computation using SPSS V. 25.0

The ANOVA shows the amount of variation in the regression model. The Value of $F$ is 57.670. $F$ test is the ratio of the overall fit of a regression. A high $\mathrm{F}-$ test signals that a model possesses significant explanatory power. The model is significant at 0.000 . This means $0.00 \%$ significant level and $100 \%$ confidence level. Since F calculated is 57.670 and F tabulated is 2.43 , that is Fcal is greater than F-tab, the null hypothesis that says there are no significant benefits of using Social Media in curbing COVID-19 importation in Nigerian Universities is hereby rejected and the alternative hypothesis accepted.

$\mathrm{H}_{03}$ : There is no problem encountered in using Video conference to curb physical contact spread of COVID-19 in Nigerian Universities.

Table-5

ANOVA

\begin{tabular}{|l|r|r|r|r|r|}
\hline & Sum of Squares & Df & Mean Square & F & Sig. \\
\hline Between Groups & 52.586 & 4 & 13.147 & 8.307 & .000 \\
Within Groups & 254.787 & 115 & 1.583 & & \\
Total & 307.373 & 119 & & & \\
\hline
\end{tabular}

Source: Author's Computation using SPSS V. 25.0

The ANOVA shows the amount of variation in the regression model. The value of $F$ is 8.307. $F$ test is the ratio of the overall fit of a regression. A high $\mathrm{F}-$ test signals that a model possesses significant explanatory power. The model is significant at 0.000 . This means $0.00 \%$ significant level and $100 \%$ confidence level. Since $F$ calculated is 8.307 and $F$ tabulated are 2.43, which are F-cal is greater than F-tab. This null hypothesis says, there is no problem encountered in using Video conference to curb physical contact spread of COVID-19 in Nigerian Universities is hereby rejected. This means that there are problems encountered in applying video conference to curb physical contact spread of COVID-19 in Nigerian Universities.

$\mathrm{H}_{04}$ : There is no prospect of Internet usage as a strategy for curbing community spread of COVID-19 in Nigerian Universities.

The ANOVA shows the amount of variation in the regression model. The Values of $F$ are 112.930 and 10.579. $F$ test is the ratio of the overall fit of a regression. A high $F-$ test signals that a model possesses significant explanatory power. The model is significant at 0.000 . This means $0.00 \%$ significant level and $100 \%$ confidence level. Since F calculated are 112.930 and 10.579 and $\mathrm{F}$ tabulated is 2.43 , that is $\mathrm{F}$-cal is greater than F-tab. This null hypothesis says there is no 
Pauline E.Onyeukwu, Abiodun Adeniyi, Hindu J.Amin

Telecommuting: A Panacea to COVID-19 Spread in Nigerian Universities

prospect of Internet usage as a tool for curbing the community spread of COVID-19 is hereby rejected.

\section{Table-6}

ANOVA

\begin{tabular}{|ll|r|r|r|r|r|}
\hline & \multicolumn{1}{|c|}{$\begin{array}{c}\text { Sum of } \\
\text { Squares }\end{array}$} & df & \multicolumn{1}{c|}{$\begin{array}{c}\text { Mean } \\
\text { Square }\end{array}$} & $\mathrm{F}$ & Sig. \\
\hline $\begin{array}{l}\text { Internet Usage } \\
\text { enhances the }\end{array}$ & $\begin{array}{l}\text { Between } \\
\text { Groups }\end{array}$ & 131.623 & 4 & 32.906 & 112.9 & .000 \\
curbing of & Within Groups & 46.913 & 115 & .291 & 30 & \\
community spread. & Total & 178.536 & 119 & & \\
IU increases the & Between & 46.129 & 4 & 11.532 & 10.57 & .000 \\
curbing community & Within Groups & 175.515 & 115 & 1.090 & 9 & \\
spread. & Total & 221.645 & 119 & & & \\
\hline
\end{tabular}

Source: Author's Computation using SPSS V. 25.0

$\mathrm{H}_{05}$ : There is no relationship between Telecommuting practices and the curbing of the spread of COVID-19 in Nigerian Universities.

The Pearson correlation test result below shows .632 (or 63.2\%) relationship between Telecommuting and the spread of COVID-19 with a Sig. value of .000. This means that there is a strong and significant positive relationship between the Telecommuting and the spread of COVID-19; such that $63.2 \%$ increase in Telecommuting will automatically lead to $63.2 \%$ increase in curbing the spread of COVID-19.

Table-7

Correlations

\begin{tabular}{|ll|r|r|}
\hline & & Telecommuting & Spreading of COVID-19 \\
\hline \multicolumn{1}{|c|}{ Pearson Correlation } & 1 & $.632^{* *}$ \\
Telecommuting & & .000 \\
& Sig. (2-tailed) & 119 & 119 \\
& $\mathrm{~N}$ & $.632^{* *}$ & 1 \\
Covid-19 & Pearson Correlation & .000 & 119 \\
spread & Sig. (2-tailed) & 119 & 119 \\
& $\mathrm{~N}$ & &
\end{tabular}

**. Correlation is significant at the 0.01 level (2-tailed).

Source: Author's Computation using SPSS V. 25.0

The results of the correlation results above are contrary to the (null) hypothesis stating that there is no relationship between telecommuting practices and the spread of COVID-19.

\subsection{Discussion of Findings}

Empirical evidence from the inferential analyses in the preceding section is succinctly discussed as follows. First, we found that online teaching has a significant effect on social distancing. Nowadays, there is continuous and ever-increasing demand by customers for remote activities to curb the spread of COVID-19. This is because customers are increasingly becoming aware of 


\section{Pauline E.Onyeukwu, Abiodun Adeniyi, Hindu J.Amin \\ Telecommuting: A Panacea to COVID-19 Spread in Nigerian Universities}

the benefits of telecommuting in the educational sector. Thus, Universities cannot afford to be fussed-out of the business; hence, they strive to ensure quality services. This finding is in line with the empirical submissions of many researchers in this study.

Second, Since F calculated is 57.670 and F tabulated is 2.43 , that is F-cal is greater than F-tab, the null hypothesis that says there are no significant benefits of using Social Media in curbing COVID-19 importation in Nigerian Universities is hereby rejected and the alternative hypothesis accepted.

Also, it was revealed that $\mathrm{F}$ calculated is 8.307 and $\mathrm{F}$ tabulated is 2.43 , F-cal is greater than $\mathrm{F}$ tab. This null hypothesis says, there is no problem encountered in using Video conference to curb physical contact spread of COVID-19 in Nigerian Universities is hereby rejected. This means that there are problems encountered in applying video conference to curb physical contact spread of COVID-19 in Nigerian Universities. Some of these challenges are inadequate electric power supply, poor network services from internet providers, lack of support to lecturers in buying top-up, and insufficient knowledge of the use of internet software.

Another finding of this study is that the F-calculated are 112.930 and 10.579 and $\mathrm{F}$ tabulated is 2.43 , that is F-cal is greater than F-tab. This null hypothesis says, there is no prospect of Internet usage as a tool for curbing the community spread of COVID-19 is hereby rejected. This means that there are prospects of Internet usage as a strategy for reducing the community spread of COVID-19 in Nigerian Universities. Evidence from many researchers has shown that the use of internet usage in Nigerian Universities is capable of controlling the community spread of the Virus.

Lastly, it was discovered that there is a significant relationship between telecommuting activities and the curbing of COVID-19 spread in Nigerian Universities. The Pearson correlation test result below shows .632 (or $63.2 \%$ ) relationship between Telecommuting and the spread of COVID19 with a Sig. value of .000 . This means that there is a strong and significant positive relationship between the Telecommuting and the spread of COVID-19; such that $63.2 \%$ increase in Telecommuting will automatically lead to $63.2 \%$ increase in curbing the spread of COVID-19.

\section{Conclusions and Recommendations}

In line with the findings, the paper finds online teaching has a significant effect on social distancing. Nowadays, there is continuous and ever-increasing demand by customers for the use of remote activities to curb the spread of COVID-19. This is because stakeholders are increasingly becoming aware of the benefits of telecommuting in the educational sector. There are significant benefits of using social media in curbing COVID-19 entering the Nigerian Universities. Therefore, the use of social media is crucial for learning. Universities should encourage their actual usage in schools and discourage fake news that is usually associated with the use of social media. We've also encountered problems in applying video conference to curb physical contact spread of COVID-19 in Nigerian Universities. Some of these challenges are identified, such as inadequate electric power supply, poor network services from internet providers, lack of support to lecturers in buying top-up and insecurity because of internet fraudsters. There are prospects of Internet usage as a strategy for curbing the spread of COVID19 in Nigerian Universities. Evidence from many researchers has shown that the use of internet usage in Nigerian Universities is capable of controlling the community spread of COVID-19. There is a strong and significant positive relationship between the Telecommuting and the spread of COVID-19; such that a $63.2 \%$ increase in Telecommuting will automatically lead to a $63.2 \%$ increase in curbing the spread of COVID-19.

The paper recommends that Nigerian Universities should adopt online Teaching as an alternative to traditional teaching. This would enable a smooth process of academic schooling in case of 
any future disease outbreak. The use of Social media should be encouraged in all academic circles in Nigeria, from primary to Tertiary education to overcome coronavirus and other future disease outbreak in the country. All Nigerian Schools from primary to Tertiary must be ICT compliant to promote telecommuting. University Management should motivate their lectures by paying them to stipend for a top-up, regular training on the use of ICT tools and ensure adequate electric power supply to avoid all interruptions in online classes. Ministry of education should make sure that only ICT compliance Institutions should be given the licence to operate in Nigeria. This would help the use of telecommuting in all the learning Institutions in Nigeria. They are thereby reducing the spread of COVID-19 and any other disease that might surface in the future. Nigerian Government should make sure that there is an uninterrupted electric power supply nationwide to enable telecommuting to be efficient and effective.

\subsection{Limitations of the Study}

Lecturers were not adequately represented in the survey; they are $28.4 \%$ while students were $71.6 \%$ of the total population of One Hundred and Nineteen respondents. The size of the population was also a limitation. This is because the population of this study did not fully represent the lecturers and students in Nigeria Tertiary Institutions.

Acknowledgements: Authors are grateful for the contributions rendered to them by the Editors of this prestigious Journal on the original manuscript. Their valuable help enhanced the quality of this paper in this present form.

\section{References}

- Anderson, A. J., \& Vega, R. P. (2015). The Impact of Telework on emotional Experience: when, and for Whom, does Telework improve daily affective will Being/. European Journal of Work and Organizational Psychology, 882-897. Crossref

- Armstrong, M. (2006). Human Resource Management Practice. India: Gopsons Paper Ltd.

- Baba-Ahmed, D. (2020, April 10). A Second Approach to Covid-19. The Podium.

- Beer, M., Spector, B., Lawrence, P., Quin, M., Walton, \& R. (1984). Managing Assets. New York: Free Press.

- Central Bank of Nigeria. (2015). 2015 Annual Report. Abuja: CBN, Nigeria.

- Charalampous, M., Grant, C. A., Tramontano, C., \& Michailidis, E. (2019). Systematically Reviewing Remote e-workers' well-being at Work: A Multidimensional Approach. European Journal of Work and Organizational Psychology, 51-73. Crossref

- Clement, J. (2019). Several Internet Users in Nigeria;2017-2023. Abuja: Google Search:https:www.Statista.com/statistics/484918/Internet-user-reach-nigeria.

- Daft, R. L. (2012). Management. Ohio: Mason Publisher.

- Duxbury, L., Higgins, C., \& Irving, R. (2016). Attitudes of Managers and Employees to Telecommuting. Online Publication, 273-285. Crossref

- Ellis, S. T., \& L, W. (2016). Innovativeness of Information Systems Managers toward Telecommuting: A Structural Equation Model. Online Publication, 92-98.

- Eze, F. (2006). Human Resources Management in Nigeria. Enugu: Mekanand.

- Fay, M. J., \& Kline, S. L. (2011). Coworker Relationships and Informal Communication in high -Intensity Telecommuting. Journal of Applied Communication Research, 144-163. Crossref

- Fombrun, C. J., TichyN.M, \& Devana, M. (1984). Strategic Human Resources Management. New York: Wiley.

- Fonner, K. L., \& Roloff, M. E. (2010). Why Teleworkers are more satisfied with their jobs than are office-based workers: When less Contact is beneficial. Journal of Applied CommunicationResearch, 336-361. Crossref

- Freedom House Index,(FHI). (2019). Degree of Internet Freedom in Sub-Sahara Africa by Country. Washington, DC: Google Search;http:/www.freedomhouse.org/report/methodology-freedom-worid-2019. 
- Guimaraes, T., \& Dallow, P. (Online Publication, 2017). Empirically Testing the Benefits, Problems and Success Factors for telecommuting Programmes. European Journal of Information Systems, 40-54. Crossref

- Guthrie, R. (2007). The Ethics of Telework. Information Systems Management, 2932. Crossref

- Handy, S. L., \& L, M. P. (2007). Planning for Telecommuting Measurement and Policy Issues. Online Publication, 99-111. Crossref

- Hornby, A. (2010). Oxford Advanced Learner's Dictionary,8th edition. UK: Oxford University Press.

- Ihekweazu, C. (2020). Physical Distancing, not Social Distancing. Abuja: Presidential Task Force Briefing on Covid-19, Channel Television.

- Khalifa, M., \& Etezadi. (2016). Telecommuting: A Study of Employees' Beliefs. Online Publication, 78-85.

- Onyeukwu, P. E., \& Mehmet, F. Y. (2012). Analysis of Workforce Performance and Reward System in Nigerian Organizations. Journal of Social and Policy Research, 19-30.

- Onyeukwu, P., Akanegbu, B., \& Igbokwe, A. (2016). Third Wave Technology and Educational Sector in the Global South. Journal of Teaching and Education, 319-333.

- Robbins, S. P., a, J. T., \& Seema, S. (2007). Organizational Behavior. India: Dorling Kindersley.

- Spillman, R. D., \& Markham, F. B. (2016). Telecommuting: Acceptance, Adoption and Application. Online Publication, 8-12.

- Spillman, R. D., \& Markham, F. B. (2016). Telecommuting; Acceptance, Adoption and Application. Journal of Computer information systems, 8-12.

- Stephens, G. K., \& Szajna, B. (2015). Perceptions and Expectations: Why People Choose a Telecommuting Work Style. International Journal of Electronic Commerce, 70-85. Crossref

- Tustin, D. H. (2014). Telecommuting Academics within an Open Distance Education Environment of South Africa: More Content, Productive and Healthy? The International Review of Research in Open and Distributed Learning. Crossref

- Webster. (2003). The New International Webster's Comprehensive Dictionary of English Language. Florida: Typhoon International Corp.

- Weihrich, H., \& Harold, K. (2005). Management A GLOBAL PERSPECTIVE. India: Tata McGraw-Hill.

- Westfal, I. R. (2007). The Telecommuting Paradox. Information Systems Management, 1520. Crossref 